\title{
Assessing the economy-wide effects of climate change adaptation options of land transport systems in Austria
}

\author{
Gabriel Bachner ${ }^{1}$ (D)
}

Received: 6 August 2015/Accepted: 28 November 2016/Published online: 26 December 2016

(c) The Author(s) 2016. This article is published with open access at Springerlink.com

\begin{abstract}
Due to climate change, transport systems are expected to become increasingly stressed by extreme weather and gradual climatic changes, resulting in direct costs within the affected sectors as well as indirect costs from sectoral interlinkages. To reduce these costs, sectorspecific climate change adaptation measures are needed, raising the question of the net benefits of adaptation at a macroeconomic level. However, despite their importance such assessments of impacts and adaptation at the macrolevel are scarce and coarse in their implementation. This paper contributes to fill this research gap by analyzing specific adaptation measures for the road and rail sectors in Austria using a computable general equilibrium model. The findings are as follows: First, direct impact costs more than double due to macroeconomic linkages. Hence, the indirect costs are found to be larger than the direct costs. Second, when analyzing adaptation measures for the road and rail sectors, without capturing any indirect effects, benefit-cost ratios imply a clear benefit only for the rail sector. However, when indirect effects via sectoral interlinkages are also captured, adaptation measures in both sectors, road and rail, clearly pay off. Climate change-induced GDP and welfare losses are reduced by 55 and $34 \%$ and lead to positive employment effects. Third, even at rather low
\end{abstract}

Editor: Ülo Mander.

Electronic supplementary material The online version of this article (doi:10.1007/s10113-016-1089-x) contains supplementary material, which is available to authorized users.

Gabriel Bachner

gabriel.bachner@uni-graz.at

1 Wegener Center for Climate and Global Change, University of Graz, Graz, Austria damage reduction potentials, adaptation leads to a net benefit at the macroeconomic level.

Keywords Climate change - Transport - Impacts · Adaptation - Macroeconomic $\cdot$ Computable general equilibrium

JEL Classification C68 · Q51 - Q54 - Q58 · R42

\section{Introduction}

Developed economies are characterized by a high degree of division of labor and therefore rely on reliable transport infrastructures and services to maintain production processes. The high dependency of modern economies on transport services has led to substantial emissions of $\mathrm{CO}_{2}$; in fact, $23 \%$ of global $\mathrm{CO}_{2}$ emissions are attributed to transport (Sims et al. 2014). In turn, climate change has manifold impacts on the transport system; in particular, infrastructures are affected by extreme weather events such as flooding, storm surges and sea level rise (Koetse and Rietveld 2009; Nemry and Demirel 2012; Regmi and Hanaoka 2011). Given the strong cross-sectoral linkages of the transport sector, the question of macroeconomic effects-capturing direct and indirect consequences - of damaged and disrupted transport systems must be addressed in order to develop and implement sound climate (adaptation) policies.

The primary tool to evaluate the total macroeconomic costs of climate change is integrated assessment models (IAMs). The strength of IAMs is their capability to capture the interaction between the economic and the climate system. IAMs have become state of the art in macroeconomic climate change impact modeling. Many different models have been developed for impact assessments [e.g., 
DICE (Nordhaus 1992), FUND (Tol 1997) or PAGE (Hope 2006)] and also developed further to include adaptation (e.g., AD-DICE (de Bruin et al. 2009a, b). However, IAMs are increasingly regarded as limited in their usefulness, since the underlying parameters and damage functions are subject to high uncertainties and often chosen ad hoc and arbitrarily (Pindyck 2013). In addition, IAMs work on a highly aggregated level with only few sectors, or even no sectoral differentiation at all.

As an alternative to IAMs, the approach of combining computable general equilibrium (CGE) models with impact cost data has emerged (OECD 2015). CGE models are macroeconomic optimization models, consisting of a multitude of producers and consumers, who simultaneously maximize profits and consumption under technological and budget constraints (Shoven and Whalley 1992; Lofgren et al. 2002). Via endogenous adjustment of relative market prices, this optimization eventually leads to a flow equilibrium in which all markets are cleared. As opposed to IAMs, which work at a highly aggregated level, CGE models explicitly differentiate between a multitude of economic sectors and in some cases also more than one consumer, and most importantly also comprise the linkages between them. Thus, CGE models are able to reveal how localized "shocks," such as climate change impacts in a certain sector, affect the whole economic system via changes in relative prices. Hence, CGE models are well suited to analyze the macroeconomic consequences of climate change impacts and adaptation and are able to reveal the indirect effects.

Yet, despite their importance, comprehensive macroeconomic studies on climate change impacts in the transport system are scarce. To the author's best knowledge, there are no IAM-based assessments which include damages to the transport system explicitly. In the most well-known CGE-based climate change impact studies for Europe, the transport system is also not included, for example in Ciscar et al. (2011) and Aaheim et al. (2012). In other studies, like in Ciscar et al. (2014), Watkiss (2011) or Bednar-Friedl et al. (2015), impacts on the transport sector are taken into account, however, still in a very rudimentary way: They either assume that households' consumption structure changes toward more expenditure for transport, which implies that the costs are fully borne by private households, or that the economy's general capital stock decreases, which is problematic, since this would mean that the most capital intensive sectors are bearing the costs; however, in reality it is the transport sectors themselves who are affected by the costs in the first place.

Most of the published literature on the costs of climate change impacts on transport systems focuses either on qualitative predictions (e.g., flooding will become more relevant; cf. Arent et al. 2014) or on the sectoral costs of certain subsystems such as impacts on pavements, safety, disruption of services (Chinowsky and Arndt 2012; Chinowsky et al. 2010; Larsen et al. 2008). The latter use detailed engineering-based models or "engineering rules of thumbs" (Larsen et al. 2008, p.442) to estimate costs. One strand of literature investigates how water borne transport is affected by climate change (Beuthe et al. 2014; Hawkes et al. 2010; Schweighofer 2014) and use changes in river water depth to deduce changes in transport costs (which seem to be limited, however, depending on the analyzed region). Another strand of literature focuses on transport systems of urban areas, such as Arkell and Darch (2006), Kirshen et al. (2008, 2006), OCA (2005) or LCCP (2005), concluding that the costs of climate change can be substantial, if no (early) adaptation measures were put in place (see Hunt and Watkiss (2011) for a review on climate change impacts in cities). Yet, all these studies do not account for economy-wide effects.

With regard to the macroeconomic consequences of adaptation, the literature is even scarcer than the literature on impacts. Aaheim et al. (2011, 2012), for example, include adaptation, but only to a very limited extent: Solely pricedriven changes in demand are included-also called $a u$ tonomous adaptation-but any institutional and/or infrastructural changes are neglected. Another caveat of Aaheim et al. $(2011,2012)$ is the inability to decompose the effects between impacts and autonomous adaptation as both happens at the same time within the same endogenous optimization procedure. In contrast, planned adaptation actively changes structures in order to reduce climate change impacts either through operational and institutional changes ${ }^{1}$ or by building new and adapting existing infrastructure. ${ }^{2}$ Only a few assessments of planned adaptation have been carried out on a macroeconomic level. There are some studies on sea level rise (Bosello et al. 2012; Darwin and Tol 2001; Deke et al. 2001); however, regarding planned adaptation for transport systems, macroeconomic studies are not available (at least to the best knowledge of the author).

In this paper, we therefore fill this research gap by carrying out a macroeconomic assessment of climate change impacts and planned sector-specific adaptation measures in the road and rail sector. We use a CGE model with a high resolution of the transport system. The analysis is carried out for the case of Austria, a country lying in Europe's Alpine Region confronted with relatively strong average temperature increases and severe flood events in recent decades. Until 2050 Austria expects further warming and an intensification of extreme precipitation events

\footnotetext{
1 Soft measures such as changing how economic activity is carried out in certain sectors or by certain actors.

${ }^{2}$ Hard measures like improving resilience by retrofitting, building safety fences or dikes.
} 
(Gobiet et al. 2014; Hofstätter and Mattula 2010; KrompKolb et al. 2014). As these climate change effects hold for many other regions, the results and revealed mechanisms are also transferrable to other countries with similar economic structures.

Methodologically, the underlying paper contributes to the literature on CGE-based macroeconomic climate change impact assessments (e.g., Aaheim et al. 2012; Berrittella et al. 2006; Bigano et al. 2008; Bosello et al. 2012; Ciscar et al. 2014) but extends the state of the art analysis by (1) modeling the transport system at a high sectoral resolution allowing the assignment of impacts to activities within the transport system, and by (2) integrating non-market-driven ("planned" as opposed to "autonomous") sectoral adaptation which in turn lead to macroeconomic and welfare effects.

To summarize, the objectives of the paper are as follows. First, we want to reveal the current climate-induced direct damage costs and how potential future impact costs can be reduced by adaptation measures. Second, we are interested in the economy-wide effects of climate change impacts and adaptation. Therefore, we apply a CGE model of Austria's economy and introduce climate change impacts as well as a bundle of adaptation measures to see how GDP, welfare and sectoral output are affected. As we are specifically interested in the different characteristics of hard and soft adaptation options, we also analyze their economy-wide effects separately. Due to the large uncertainties regarding the damage reduction potential of adaptation measures, we additionally carry out a sensitivity analysis to find the threshold of necessary damage reduction at which a net benefit from adaptation at a macroeconomic and societal level is generated.

The analysis is carried out in three steps. First, we elaborate the current average annual weather-induced damage costs in the road and rail transport sectors. This provides insights into sectoral vulnerability and the underlying data for the second step: obtaining sectoral and macroeconomic costs of possible future climate change impacts until 2050, including the indirect costs. Using a CGE model, we are able to show by how much direct costs are amplified within the economic system. In the third and final step, we introduce adaptation measures, inducing new costs but also reducing damages.

The remainder of the paper is structured as follows. In Sect. 2 current weather-induced damage costs, future climate change impacts as well as possible adaptation options are monetized for Austria's road and rail sector. Section 3 describes the methodology and the applied model. Section 4 provides the main results of the study, which are described firstly at the sectoral level and then from the macroeconomic perspective, including an analysis regarding damage reduction potentials of adaptation measures. Section 5 gives discussion and conclusions.

\section{Data: current damages, future impacts and adaptation}

\section{Current damage costs}

Regarding current damage costs, we use data from Doll and Sieber (2010) who provide costs for certain European regions (including the Alpine region, consisting of Switzerland, Austria and Slovenia) and also some data at country level (including Austria). Damage costs are subsumed into the four impact categories: Flood and Rain, Ice and Snow, Storm as well as Heat and are given for the time period of 2000-2010. Each of these categories directly impacts on the cost categories Infrastructure, Vehicles and/ or Users, triggering sectoral damage costs. From this database current costs for Austria's road transport sector are extracted, either by taking over directly the given costs for Austria, or by scaling down the costs in the Alpine Region using Austria's share of road network length in the Alpine Region (53\%; based on European Union, 2012). In total the costs in the road transport sector sum up to $€ 47 \mathrm{M}$ per year. When analyzed across cost categories, the lion's share of costs is attributable to damages to infrastructure assets ( $€ 39$ M p.a.; $82 \%$ of total), the second largest cost component is damages to vehicles ( $€ 5 \mathrm{M}$ p.a.; $10 \%$ of total). Regarding the impact categories, $67 \%$ of damage is triggered by Flood and Rain, $19 \%$ by Ice and Snow, $8 \%$ by Storm and $6 \%$ by Heat.

Regarding the rail sector, we draw again on data from Doll and Sieber (2010) and in addition to information of personal communications with sector experts. Compared to the road sector there is one additional cost category, namely Service, since there is one central service provider which is responsible for detouring in the case of disruptions. The current average annual weather-induced costs in the rail sector are $€ 18 \mathrm{M}$; thereof $88 \%$ ( $€ 16 \mathrm{M}$ ) attributable to Infrastructure, and about 4\%, respectively, to Vehicles, User and Service. Regarding the distribution across impact categories, about 95\% of all infrastructure damages are triggered by Flood and Rain. Vehicle damages are triggered mainly by Flood and Rain $(70 \%)$ as well as Storm $(20 \%)$. For more details on current damage data, please see the online supplementary material (Tables OSM-1 and OSM-2).

Comparing infrastructure damage costs between the road and rail transport sectors, the costs are two to three times larger in the road sector. However, when put into perspective by network length [124,000 km road network and $5000 \mathrm{~km}$ rail network (European Union 2012 and 
ÖBB2014, respectively)], we see that damages are about $300 € / \mathrm{km}$ in the road transport sector and $3300 € / \mathrm{km}$ in the rail sector. Thus, damage events concerning infrastructure are eleven times costlier in the rail sector than in the road sector. ${ }^{3}$

\section{Climate change impacts}

According to Kromp-Kolb et al. (2014) climate change in Austria is characterized by an increase in average temperature of nearly $+2{ }^{\circ} \mathrm{C}$ since 1880 (in contrast to $+0.85{ }^{\circ} \mathrm{C}$ on a global scale) and further temperature increase is expected $\left(+1.4{ }^{\circ} \mathrm{C}\right.$ until 2050 relative to current temperatures). Regarding extreme precipitation events, the Alpine region (including Austria) expects an intensification, especially in the winter season (Frei et al. 2006; Gobiet et al. 2014; Hofstätter and Mattula 2010).

Concerning future economic losses, Jongman et al. (2014, p.1) state that "observed extreme flood losses could more than double in frequency by 2050 under future climate change and socio-economic development." Also Aaheim et al. (2012) assume that the frequency of natural hazards doubles. This assumption should reflect an increase in temperature of $+3.5^{\circ} \mathrm{C}$, which in turn is well in line with the expected temperature increase in Austria $\left(+2{ }^{\circ} \mathrm{C}\right.$ since 1880 and further $+1.4 \%$ until 2050; Kromp-Kolb et al. 2014). Taking these studies as a yardstick and given that the major impact category for Austria's transport infrastructures is Flood and Rain (including mudflows and landslides), we assume a doubling of current weather-induced impact costs in Austria's land transport sectors due to climate change until 2050.

\section{Climate change adaptation}

Regarding adaptation, we consider seven technical and planned adaptation measures which are implemented in the road and rail transport sectors to reduce climate change impacts (see Table 1). Starting with the road transport sectors, the first measure is the enlargement of drainage system capacities alongside roads by $+20 \%$, with total investment costs of $€ 130 \mathrm{M}$ (based on Altvater et al. 2012) and annual costs of $€ 4 \mathrm{M}$ (assuming 30 years until full depreciation). Second, vegetation management next to roads is intensified by $20 \%$, leading to annual personnel costs of $€ 14 \mathrm{M}$ plus $€ 7 \mathrm{M}$ material costs (ACA 2013).

\footnotetext{
3 One explanation for this difference is the value of the regarded infrastructure. Dulac (2013) gives construction costs per lane-km and track-km for roads and rail respectively which are 4-5 times higher for rails. Furthermore, since many of the damaged roads lie in remote areas of Austria where often only gravel roads are in place, the average value of roads being affected is even smaller, explaining another part of the cost gap.
}

Third, early warning systems are improved by installation of additional hydrological stations. Total investment costs for this measure are about $€ 1 \mathrm{M}$, leading to $€ 0.1 \mathrm{M}$ annual depreciation, and operating costs for maintenance are $€ 0.2 \mathrm{M}$ (Altvater et al. 2012). Finally, the frequency of visual road inspection is doubled. Because of this measure, severe damages due to frost and heat are prevented, as damages can be detected and repaired earlier. This costs about $€ 1$ M per year (ACA 2013).

For the rail sectors, less information can be gathered from the literature. Therefore, we apply the first two measures from the road sectors equivalently to the rail sectors: First, drainage system capacities are enlarged by $+20 \%$, leading to annual costs of $€ 0.2 \mathrm{M}$. Second, vegetation management is intensified by $+20 \%$, resulting in annual personnel costs of $€ 0.7 \mathrm{M}$ and $€ 0.4 \mathrm{M}$ material costs.

As a final and more general measure which protects road and rail transport systems (besides other non-transport infrastructure), the transport-related expenditures of the Austrian torrent and avalanche protection agency are assumed to be expanded by $+50 \%$, leading to additional annual costs of $€ 23 \mathrm{M}$. Total annual adaptation costs at the sector levels add up to $€ 51 \mathrm{M}$ (thereof $€ 27 \mathrm{M}$ in the road transport sector, $€ 1.3 \mathrm{M}$ in the rail transport sector and $€ 23 \mathrm{M}$ as a general measure).

\section{Methodology}

\section{The computable general equilibrium model}

To assess the macroeconomic effects of climate change impacts and adaptation in the transport sector, we use a CGE model. A CGE model is based on a social accounting matrix (SAM). Similar to an input-output table, a SAM depicts the economy as monetary flows between agents (i.e., producers and consumers), typically on a yearly basis. An agent's payments and income are shown as corresponding columns and rows, meaning that each cell of the matrix explicitly shows a transaction between two agents. When column sums equal row sums, all outputs are absorbed elsewhere in the system, meaning that the macroeconomy is balanced and all markets are cleared. Within this macrobalancing framework, producers generate output in order to maximize profits via the optimal combination of factors (typically labor and capital) and intermediate inputs according to a specified production function. Consumers maximize their consumption of goods and services according to a specified consumption function and are constrained by their factor endowments. A correctly calibrated CGE model replicates the annual monetary flows of the underlying balanced SAM, by solving a 
Table 1 Costs of adaptation measures in the road and rail transport sectors

Qualitative description of adaptation measures and first-order damage reduction

$\begin{array}{ll}\begin{array}{l}\text { Total investment } \\ \text { volume }\end{array} & \begin{array}{l}\text { Annualized adaptation } \\ \text { costs }\end{array} \\ {[\mathrm{M} €]} & {[\mathrm{M} €]}\end{array}$

Road

1) Enlargement of drainage systems ( $+20 \%$ capacity); (based on Altvater et al. 2012)

4.31

First-order damage reduction: reduces infrastructure damages due to flooding

2) Additional vegetation management to enhance water runoff ( $+20 \%$ increase in expenditure); (based on ACA 2013)

First-order damage reduction: reduces infrastructure damages due to flooding

3) Additional hydrological stations for early warning systems; (based on Altvater et al. 2012) 1.23

First-order damage reduction: reduces vehicles and user damages due to flooding

4) Increase in visual inspection of roads (doubling of frequency); (based on ACA 2013)

First-order damage reduction: reduces infrastructure damages due to frost and heat

\section{Sum road}

Rail

5) Enlargement of drainage systems ( $+20 \%$ capacity); (based on Altvater et al. 2012)

First-order damage reduction: reduces infrastructure damages due to flooding

6) Additional vegetation management (+20\% increase in expenditure); (based on ACA 2013) -

First-order damage reduction: reduces infrastructure damages due to flooding

Sum rail

General

7) Increase in annual expenditures for torrent and avalanche protection (e.g., fences and dams) 22.9 by $50 \%^{\mathrm{a}}$

First-order damage reduction: reduces infrastructure damages due to flooding, storm and snow and ice

Sum all

Based on (Doll and Sieber 2010; Altvater et al. 2012; ACA 2013)

a Data from personal communications with the Austrian Torrent and Avalanche Protection Agency ("Wildbach und Lawinenverbauung") are used to calculate the absolute costs of this measure

square system of inequalities, formulated as a mixed complementarity problem (see Paltsev 2004 and Rutherford 1995). The current status of the economy is thus represented as a flow equilibrium in which all markets are cleared, the so-called benchmark equilibrium. When this benchmark equilibrium is shocked (e.g., an extreme weather event), the agents maximize profits and consumption under new circumstances, leading to endogenous changes in relative prices as well as supplied and demanded quantities. This happens until a new equilibrium emerges, in which all markets are cleared again. By comparing model variables prior and after shocking the model, it is possible to capture macroeconomic effects (see Lofgren et al. 2002 for a comprehensive description of the functioning of CGE models). CGE models are thus well suited to analyze economy-wide effects triggered by a localized shock.

The here-applied CGE model is based on Bachner et al. (2015). Austria's economy is modeled as a comparative static small open economy based on Austria's input-output table of 2008. A representative private household is endowed with the production factors labor and capital, which are supplied to the market and generate household's income. Income is spent on consumption according to a nested constant elasticity of substitution (CES) function and on annual investments. Investments are determined by a fixed savings rate and annual depreciation. In total, there are 46 economic production sectors, combining factors and intermediate inputs (i.e., outputs from other sectors) according to nested CES production functions to generate output. Domestically produced goods are either used within the country or are exported to the rest of the world according to a constant elasticity of transformation (CET) function. Exporting goods generates foreign exchange, which is then used to buy imports. Following the "Armington assumption", imports and domestically produced goods are imperfect substitutes (Armington 1969) and are thus traded off according to sector-specific elasticities of trade. ${ }^{4}$ The government collects taxes which are levied on

\footnotetext{
$\overline{4}$ The export volume is thus determined by world market and domestic prices as well as by elasticities of substitution.
} 
labor and capital inputs as well as on production, consumption and exports (fixed tax rates). Tax income is spent on government consumption and on transfers to the household. Regarding the labor market, classical unemployment is introduced via a minimum wage, meaning that the amount of provided labor adjusts endogenously such that the minimum wage is met.

Special emphasis is given to the resolution of the land transport sector: The original land transport sector is disaggregated ${ }^{5}$ into three transport infrastructure-providing sectors (STROAD for road, STRAIL for rail and STREST for the rest of transport infrastructure providers), two rail transport service sectors (FRRAIL for freight and PSRAIL for passenger transport), one sector for shortrange public passenger transport $(S H T R)$, one sector for road freight transport services (FRROAD) and one sector which is providing the rest of land transport services (REST, e.g., taxi operation, long range buses, transport via pipelines.). Motorized individual transport (MIT) of the representative household is modeled as a separate activity. All economic sectors need, next to other intermediate inputs, a transport services "aggregate" as input in order to operate. This aggregate is modeled using a nested CES function, combining transport services, which are generated by the transport service providing sectors, again according to a nested CES production function. In addition, transport service providers need transport infrastructure as an input in order to operate. The representative private household consumes, next to all other consumption goods, public transport as well as MIT. For a detailed description of the model (including the mathematical formulation, sectoral production functions as well as the household's consumption function) please see the OSM (Sect. 2).

\section{Modeling climate change impacts}

The current weather-induced costs to the transport sectors are already calibrated within the benchmark equilibrium of the CGE model. Consequently, shocking the model with the current damage costs (described in Sect. 2.1) corresponds to a doubling of current damages and therefore represents the underlying climate change impact scenario we want to explore. Hence, we actually analyze the climate change impacts of 2050 in today's economy, a commonly chosen approach [see e.g., Ciscar et al. (2011) or Halsnæs et al. (2007)] with the advantage of not having to make any

\footnotetext{
5 The disaggregation of the land transport sectors (NACE code H49 [Land transport] and H52_53 [Warehousing and support activities for transportation]) is based on EUROSTAT (2014) as well as on data from annual reports of transport companies in Austria.
}

assumptions about the future development of the economy as well as discounting. ${ }^{6}$

Climate change impacts-expressed as direct economic damage costs in euros-are transferred into the CGE model to reveal the macroeconomic and societal costs of climate change impacts in terms of GDP and welfare. Damages to infrastructure are modeled as higher average annual depreciation in infrastructure-providing sectors, meaning higher capital demand. This means that we alter the production functions of the respective transport sectors in terms of lower productivity, which then translates into higher market prices, affecting all other agents. The corresponding additional investment expenditures are paid to the construction sector, crowding out other investments. ${ }^{7}$ Other impacts are captured as changes in operating costs of economic sectors and changes in households' consumption using shifting parameters across the production or consumption function, respectively. Regarding time and safety losses of private households due to traffic interruptions and accidents, the welfare measure is adjusted ex post. ${ }^{8}$

\section{Modeling climate change adaptation}

In general, we differentiate between hard and soft adaptation measures. Hard measures involve the construction of protective infrastructures and are therefore implemented in the model through higher sectoral depreciation (capital input) and more investment towards the construction and machinery sectors. This is true for the measures enlargement of drainage systems, additional hydrological stations as well as increased annual expenditures for torrent and avalanche protection. Note that we handle impacts and adaptation differently concerning investments. As opposed to unanticipated impacts, adaptation is regarded as a planned and anticipated activity and therefore economy-wide investments are expanded. This expansion of investments is carried out by the government and funded by tax increases, which in turn reduce households' consumption. Soft measures are modeled via more sectoral labor demand and a shift in running costs to machinery

\footnotetext{
${ }^{6}$ In contrast, other studies such as Steininger et al. (2015) construct a baseline scenario for a future economic development, including assumptions regarding annual growth, future demand and production patterns, climate policy etc.

$720 \%$ of damaged infrastructure is assumed to be already fully depreciated. Therefore the true costs in terms of additional capital costs are only $80 \%$.

${ }^{8}$ To measure welfare we use the Hicksian equivalent variation, which is based on goods and services which are consumed as final demand within the whole economy. The change in welfare in euros measures the lost consumption possibilities due to price changes, or equivalently the necessary payments to compensate for the welfare loss. Since the CGE model is not able to capture time and safety losses, the equivalent variation is adjusted after the model has been shocked and found a new equilibrium.
} 
(material costs). The corresponding measures are additional vegetation management alongside roads and rail tracks as well as increase in visual inspection of roads. Since capital is scarce, whereas labor can be provided additionally via the labor market, different effects are expected to emerge between hard and soft measures.

Regarding the benefits of adaptation, we introduce the concept of damage reduction potential (DRP). Every adaptation measure has a certain DRP, meaning that each measure aims at specific impact categories (see Table 1) reducing the respective damages or costs to a certain extent. The cost reduction works in three ways: First, damages or costs can be reduced directly by a measure, representing "first-order damage reduction" (e.g., the enlargement of drainage systems reduces the damages by flooding to roads directly). The damage reduction $D R$ (in \%) for a certain cost category $i$ is determined multiplicative by $D R_{i}=1-\prod_{a} r_{i, a}$. Parameter $r_{i, a}$ is the direct reduction factor to reduce damages to cost category $i$ (e.g., infrastructure assets), using adaptation measure $a$ (e.g., enlargement of drainage systems), aiming at impact category $j$ (e.g., Flood and Rain). Second, there is a second-order effect of adaptation (explained by parameter $s_{\text {infra }}$ ) whenever a measure that protects infrastructure also reduces damages or costs elsewhere (e.g., less time or safety losses). In that case, damage reduction $D R_{i}$ is extended to $D R_{i}=1-\prod_{a} r_{i, a} * s_{\text {infra }}$. Third, as road and rail infrastructure often run close to each other, there are "co-benefits" across transport sectors, meaning that the rail infrastructure benefits from protection measures for road infrastructure. ${ }^{9}$ To add these co-benefits in the model, a third parameter $c$ is introduced, capturing the co-benefits for cost category $i$ from adaptation measures $b(\neq a)$ in other transport sectors: $D R_{i}=1-\prod_{a} r_{i, a} * s_{\text {infra }} * \prod_{b} c_{i, b}$ (see OSM Sect. 3 for more details on the DRP). Note that in the real world multiple adaptation measures are often put in place as a combined effort. The "overlap" between measures is considered in this analysis, since the $D R$ is determined multiplicatively. The modeled co-benefit reflects an overlap between measures across the transport sectors.

Using this framework the direct damage cost reduction varies across cost categories and lies between 17 and $73 \%$. In general, $D R$ is higher for infrastructure assets, since most of the adaptation measures are hard measures, whereas, for instance, operation is protected mostly indirectly via the second-order effect (see Table OSM-4 in the OSM for more details).

\footnotetext{
9 Since roads and railways are often running parallel to each other there are possible co-benefits into both directions. However, as the road network is much larger than the rail network, the co-benefits in the road sector due to protected rail infrastructure is very small in relation to the whole road network length. To keep the model simple co-benefits are thus assumed only in one direction: From road to rail systems, but not vice versa.
}

As there is no information by how much the damage costs can be reduced by each measure, we start the analysis with $33 \% D R P_{a, i}, 17 \% s_{\text {infra }}$ and $6 \% D R P_{b, i}$. For the example of enlargement of drainage systems in the road sector, which protects against flood-related damages, this means that road infrastructure damages due to flooding are reduced by $33 \%$, all other impacts due to flooded infrastructure (e.g., time or safety losses) are reduced by $17 \%$, and flood-related infrastructure damages in the rail sector are reduced due to a co-benefit by $6 \%$. This procedure was carried out for all of the seven adaptation measures, depending on their specific characteristics. Due to the uncertainty regarding DRP, we go into more detail on these parameters in Sect. 4.4.

\section{Results}

\section{Sectoral analysis of costs and benefits of adaptation without economy-wide feedback effects}

Based on the chosen assumptions regarding damage reduction potentials (DRP), the annual costs ${ }^{10}$ and benefits that emerge in the road and rail sectors are summarized in Table 2 (no macroeconomic feedback effects and indirect costs, yet). In the road transport sectors, the costs after adaptation ( $€ 46 \mathrm{M}$ ) is nearly the same as the direct impact costs ( $€ 47 \mathrm{M})$, meaning that there is only a small benefit from adaptation on the sectoral level. When comparing the benefits of adaptation with the costs of adaptation, the benefit-cost ratio is 1.03 . Regarding the rail sectors, the costs after adaptation $(€ 7.5 \mathrm{M})$ are much lower than the direct impact costs without adaptation ( $€ 18 \mathrm{M})$. Here, the benefit-cost ratio is 9.57 . This high ratio exists because rather low adaptation costs are attributed to the rail sector. Hence, for the rail sectors a clear benefit from adaptation emerges $(€ 11 \mathrm{M})$. Aggregating the road and rail sectors, we see $€ 65 \mathrm{M}$ costs without and $€ 53 \mathrm{M}$ with adaptation, thus a benefit from adaptation of $€ 12 \mathrm{M}$ (a benefit-cost ratio of 1.42). Note that this analysis depends strongly on the chosen assumptions for the DRP which are tested in the sensitivity analysis in Sect. 4.4.

\section{Economy-wide effects of climate change impacts and adaptation}

For the macroeconomic and societal costs of climate change impacts and adaptation, we apply a CGE model of

\footnotetext{
10 The costs arising for the measure Increase of annual expenditures for torrent and avalanche protection are not included in Table 3 , as the attribution of protection to a certain transport sector is not possible. Besides, not only transport infrastructure is protected by this measure.
} 
Table 2 Cost-benefit analysis of direct impacts and adaptation costs in million $€$ p.a. for the road and rail transport sectors (without economic indirect feedback effects)

\begin{tabular}{lccc}
\hline & Road sectors & Rail sectors & Combined \\
\hline Direct impact costs without adaptation & 46.73 & 18.38 & 65.11 \\
Impact cost reduction by adaptation (benefit) & -27.71 & -12.16 & -39.87 \\
Residual impact costs & 19.01 & 6.22 & 25.24 \\
Adaptation costs & 26.84 & 1.27 & 28.12 \\
Costs after adaptation & 45.86 & 7.5 & 53.35 \\
benefit-cost ratio & 1.03 & 9.57 & 1.42 \\
\hline
\end{tabular}
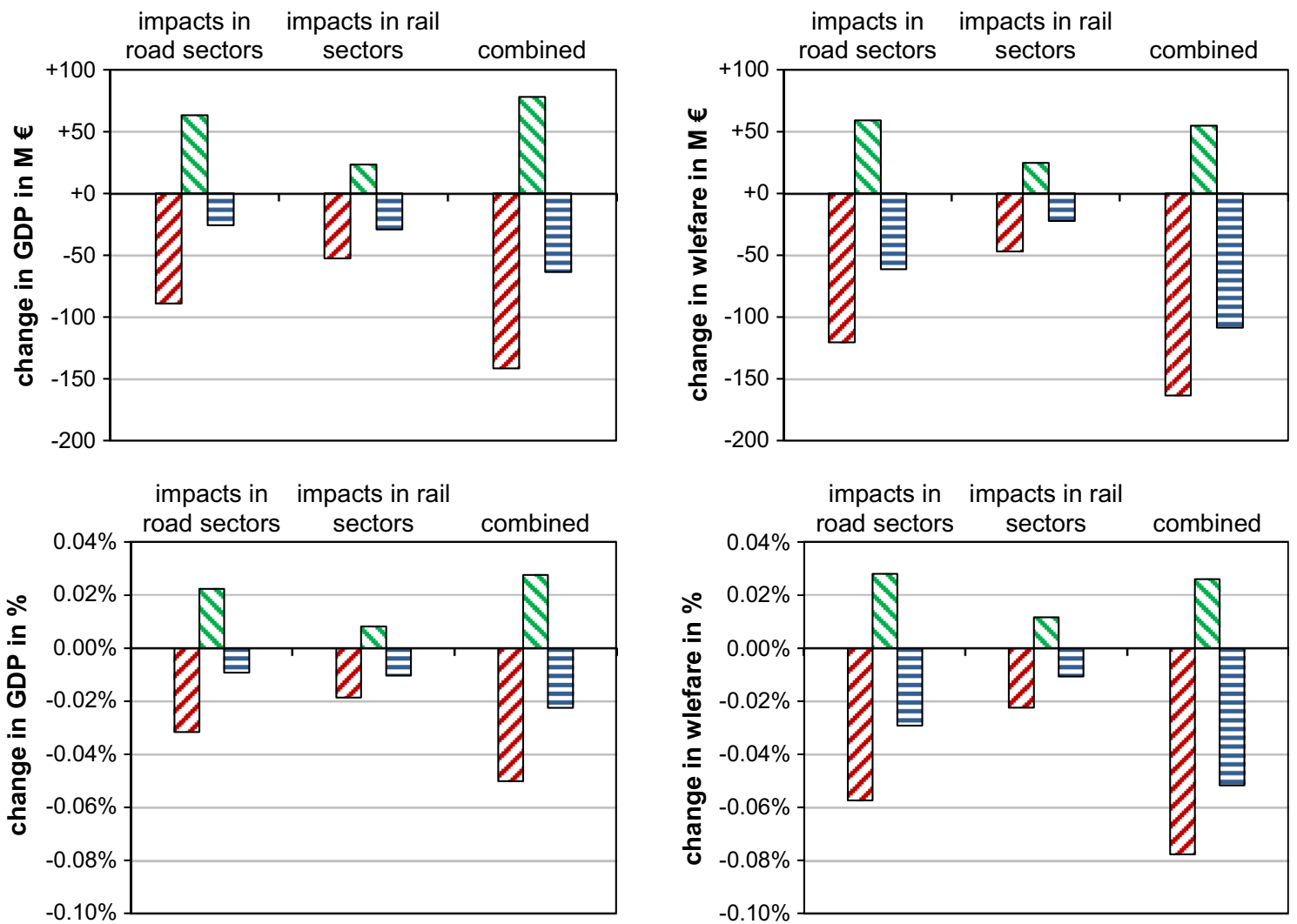

$\square$ impacts $\quad$ net effect of adaptation $\quad$ 国 residual impact

Fig. 1 Changes in GDP (left) and welfare (right) without and with adaptation to climate change in the road and rail transport sectors in M $€$ p.a. (top) and in \% (bottom) relative to the benchmark equilibrium (including indirect feedback effects)

Austria's economy and introduce the previously described climate-induced costs and the benefits of adaptation. To measure the macroeconomic effects, we compare the change in GDP and in welfare relative to the model's benchmark equilibrium. All effects are given in $€_{2008}$ as the base year of the model is 2008. Figure 1 shows the effects of GDP (left) and welfare (right) from impacts and adaptation occurring in the road and rail sectors in isolation and for a combined model run, both in absolute (top) and relative (bottom) terms.

In the combined case, climate change impacts without adaptation lead to a lower annual GDP of $-€ 142 \mathrm{M}$ $(-0.05 \%)$, whereas welfare loss adds up to $-€ 163 \mathrm{M}$ p.a.
$(-0.08 \%){ }^{11}$ When comparing the macroeconomic effect ( $-€ 142$ M GDP loss) with the actual direct sectoral costs $(-€ 65 \mathrm{M})$, we see that the direct effect is amplified by a factor of 2.2, meaning that the indirect effect is stronger than the direct effect. This strong indirect effect is rooted in the strong interconnectedness of the transport sectors to the rest of the economy. Substitution possibilities across transport modes are very limited, and thus production is affected strongly.

$\overline{11}$ The effect on welfare is stronger than on GDP, because motorized individual, which plays a large role in household's consumption $(15 \%)$, is affected negatively by higher prices for infrastructure. 
In the combined case with adaptation, GDP and welfare losses are only lower by $-63(-0.02 \%)$ and $-€ 109 \mathrm{M}$ $(-0.05 \%)$. Therefore, adaptation generates a net benefit of $+€ 79 \mathrm{M}$ of GDP and $+€ 54 \mathrm{M}$ welfare $(+0.03 \%$-points, respectively). GDP (welfare) losses are consequently reduced by $55 \%(34 \%)$.

These positive effects of adaptation are triggered, on the one hand, by the reduction in damages-meaning that the productivity losses of the transport sectors are becoming smaller - and, on the other hand, via the labor market. Since the soft adaptation measures are relatively labor-intensive, a reduction in unemployment of $0.04 \%$-points emerges, leading to more consumption and higher tax revenues.

When impacts and adaptation are only considered in the road sectors, a substantial net benefit on the macroeconomic and societal level emerges (71\% GDP and $49 \%$ welfare loss reduction) despite the unclear benefit-cost relationship at the sectoral level (see Table 3). Regarding the rail sectors, the loss reduction is somewhat smaller but still significant (44\% GDP and 52\% welfare loss reductions).

To capture the sectoral effects after macroeconomic feedbacks, we measure the changes in annual sectoral output (turnover, see Figures OSM-3 and OSM-4). In the combined impact case without adaptation, there are output losses for all economic sectors, except for the construction sector, which is stimulated by climate change-induced reconstruction activities. Regarding the transport sectors, the output losses are stronger in the rail sectors $(-1.6 \%$ in STRAIL, $-0.6 \%$ in FRRAIL and $-0.2 \%$ in PSRAIL). The output loss in the road sectors is about $-0.2 \%$. When introducing adaptation options, output losses in the rail transport sectors can be reduced by $1 \%$-point in $S T R A I L$, by $0.4 \%$-points in FRRAIL and $0.1 \%$-points in STRAIL. The effect in all other transport sectors is also slightly reduced. However, there is still a residual loss for all sectors, except for the construction sector. Its benefit from climate change impacts is reduced in the adaptation case but still remains positive, since it benefits from adaptation investments. In all other non-transport economic sectors, the net benefit of adaptation is positive, because the economy can operate more efficiently due to less severe climate change impacts.

\section{Comparison across sector-specific adaptation measures}

We now analyze how the different adaptation measures reduce macroeconomic impacts in isolation (see Table OSM-5 for details). ${ }^{12}$ In the road sector, the soft

\footnotetext{
12 Note that the sum of effects of the individual adaptation measures does not match with the effect when all measures are active at the same time because the different adaptation measures are overlapping and sometimes compete against each other in terms of protection.
}

adaptation measure vegetation management shows the strongest effect on GDP and welfare $(+€ 25 \mathrm{M}$ and $+€ 31 \mathrm{M}$, respectively). In addition to the effect of reduced impacts, this measure creates employment since it is relatively labor-intensive. It thus contributes positively to GDP. The macroeconomic benefit-cost ratio ${ }^{13}$ is 1.2 when the benefit is measured as a change in GDP and 1.5 when the benefit is measured as a change in welfare. Additional hydrological stations for early warning systems also show a rather strong effect, especially on welfare $(+€ 19 \mathrm{M}$ GDP and $+€ 26 \mathrm{M}$ ), since not only infrastructures are protected by this adaptation measure but also time and safety losses are reduced. The macroeconomic benefit-cost ratio is very high, namely 67.9 for GDP and 92.9 for welfare. This reflects the assumption that, due to rather cheap early warning systems, also infrastructure damages can be reduced, e.g., by building up mobile flood protection when a flood is expected. ${ }^{14}$

Regarding the rail sector, the two adaptation measures enlargement of drainage systems and vegetation management show about the same absolute effect (about $+€ 15 \mathrm{M}$ GDP and welfare, respectively). When using GDP (welfare) to measure the benefit, the benefit-cost ratio is 68.2 (77.3) for enlargement of drainage systems and 13.2 (15.1) for vegetation management. These rather high ratios reflect the fact that rail infrastructure is much costlier than road infrastructure and thus the resulting benefits (i.e., avoided damages) are much higher.

\section{The influence of the damage reduction potential}

As we face high uncertainties regarding damage reduction potential (DRP), we calculate the threshold by which a net benefit of adaptation is achieved at the macroeconomic level (i.e., by which the residual impact on GDP and welfare after adaptation would become smaller than the impact without any adaptation measures). Figure 2 shows the relation between GDP as well as welfare loss and the assumed DRP (combined case). The vertical solid line at $33 \%$ first-order DRP reflects the already described results. When reducing ${ }^{15}$ the DRP, we see that below $12 \%$ DRP the net welfare benefit of adaptation vanishes; however, the benefit measured in GDP is still positive. When reducing DRP below $4 \%$ also the net benefit in GDP becomes zero. Therefore, at a DRP below $4 \%$ adaptation does not pay off any more on a macroeconomic level. The curvature of the

\footnotetext{
${ }^{13}$ Costs of the measure divided by the change in GDP or welfare.

${ }^{14}$ Such walls have been installed e.g. in Austria during the summer floods of 2013.

15 First order, second order DRP and co-benefits are reduced simultaneously in the following relations: first order DRP: $-1 \%$; second order DRP $-0.5 \%$ (i.e. half of first order DRP), co-benefit $-0.17 \%$ (i.e. one third of second order DRP).
} 
Fig. 2 Relationship between damage reduction potential and annual GDP and welfare losses. Dashed vertical lines indicate thresholds for net benefit generation from adaptation measured in GDP and welfare

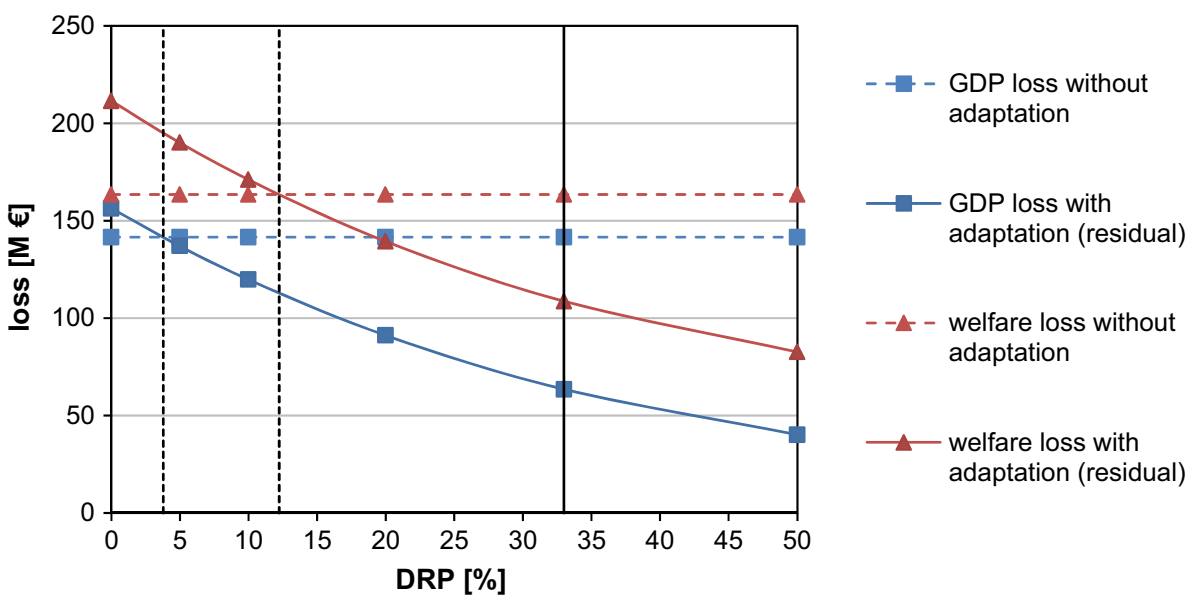

loss functions also shows that the marginal benefit of damage reduction declines with higher DRP. This is due to the multiplicative effect of the different adaptation measures' DRPs, meaning that once an adaptation measure reduces some damages (damage is multiplied by a factor $<1$ ), the next measure's damage reduction in absolute terms gets smaller.

\section{Discussion and conclusions}

By applying a computable general equilibrium (CGE) model with a high resolution of the land transport sector, we find that, when indirect effects of climate change impacts are included, the total costs of impacts are more than twice (factor 2.2) as large as the direct costs only. The indirect costs are thus even larger than the direct costs. This points out the importance of comprehensive macroeconomic approaches in order to avoid an underestimation of the costs of climate change impacts (see also Hallegatte et al. (2007) on the concept of the amplification ratio),

A second important insight is that, when it comes down to the decision of whether adaptation measures should be implemented or not, cost-benefit analyses at the sectoral level might lead to no adaptation efforts since no clear benefit might be visible. For the case of the road transport sector, we demonstrate that the sectoral cost-benefit analysis, without including economy-wide feedback effects, would be misleading, since it does not show a clear net benefit of adaptation (Table 2); however, substantial positive macroeconomic (GDP) and societal (welfare) effects are triggered (Fig. 1), when planned adaptation measures are implemented.

These positive effects of adaptation measures are particularly interesting as labor market effects are quite strong. This is due to the different natures of impacts and adaptation measures themselves. While impacts require investments to restore infrastructure, adaptation involves both investment and ongoing operation activities. As the latter are often labor-intensive, unemployment is reduced by adaptation, leading to a stimulating effect that helps offsetting macroeconomic climate change impacts. Since adaptation triggers economy-wide investments, positive effects on the labor market emerge additionally (these positive effects are not present when impacts are modeled, since other investments are crowded out). Further research on climate change adaptation should thus focus on more comprehensive methods, rather than on case study-specific cost-benefit analyses as found numerously in the literature.

Since the sectoral gains of adaptation measures are largest in the transport sectors, the question arises, whether they should also bear a part of the adaptation costs, instead of the government paying for adaptation measures and financing it through increased consumption taxes (the assumption in this paper). As adaptation stimulates positive effects throughout all economic sectors, one option would be to direct some costs also to them.

While data limitations on adaptation benefits (i.e., the damage reduction potential) remain a serious limitation of the current paper, the qualitative finding that each adaptation measure considered is beneficial at the macroeconomic scale is robust. Only with an extremely low damage reduction potential (below 4\% for GDP and below $12 \%$ for welfare; Fig. 2) would the macroeconomic net benefits of adaptation turn negative.

A critical point of the underlying analysis is that the chosen level of adaptation is limited to several quantifiable measures found in the literature. As a consequence, while we assumed that with additional measures the additional benefit (damage reduction) becomes smaller, we did not identify the efficient level for each measure nor the optimal combination of the measures. However, doing so would require addressing several problems such as the discrete nature of adaptation measures and their costs, the maximal level of possible implementation of adaptation measures, as well as the damage reduction potentials of each measure. 
Acknowledgements Open access funding provided by University of Graz. Funding for this research was Granted by the Austrian Climate and Energy Fund (Austrian Climate Research Program, Project adapt2to4). I thank Birgit Bednar-Friedl for discussions and her helpful advice. All remaining errors are mine.

Open Access This article is distributed under the terms of the Creative Commons Attribution 4.0 International License (http://crea tivecommons.org/licenses/by/4.0/), which permits unrestricted use, distribution, and reproduction in any medium, provided you give appropriate credit to the original author(s) and the source, provide a link to the Creative Commons license, and indicate if changes were made.

\section{References}

Aaheim A, Gopalakrishnan R, Chaturvedi RK, Ravindranath NH, Sagadevan AD, Sharma N, Wei T (2011) A macroeconomic analysis of adaptation to climate change impacts on forests in India. Mitig Adapt Strat Glob Change 16:229-245. doi:10.1007/ s11027-010-9266-6

Aaheim A, Amundsen H, Dokken T, Wei T (2012) Impacts and adaptation to climate change in European economies. Glob Environ Change 22:959-968. doi:10.1016/j.gloenvcha.2012.06. 005

ACA (Austrian Court of Audit) (2013) Bericht des Rechnungshofes. Bauliche Erhaltung von Landesstraßen. Reihe Tirol 2013/2. http://www.rechnungshof.gv.at/fileadmin/downloads/2013/ber ichte/berichte_laender/tirol/Tirol_2013_02.pdf. Accessed 05 May 2014

Altvater S, de Block D, Bouwma I, Dworak T, Frelih-Larsen A, Görlach B, Hermeling C, Klostermann J, König M, Leitner M, Marinova N, McCallum S, Naumann S, Osberghaus D, Prutsch A, Reif C, van de Sandt K, Swart R, Tröltzsch J, (2012) Adaptation measures in the EU: policies, costs, and economic assessment. "Climate Proofing" of key EU policies. http:// ecologic.eu/de/4827. Accessed 30 Oct 2014

Arent DJ, Tol RSJ, Faust E, Hella JP, Kumar S, Strzepek KM, Tóth FL, Yan D (2014) Key economic sectors and services, In: Field CB, Barros VR, Dokken DJ, Mach KJ, Mastrandrea MD, Bilir TE, Chatterjee M, Ebi KL, Estrada YO, Genova RC, Girma B, Kissel ES, Levy AN, MacCracken S, Mastrandrea PR, White LL (eds) Climate change 2014: impacts, adaptation, and vulnerability. Part A: global and sectoral aspects. Contribution of Working Group II to the Fifth Assessment Report of the Intergovernmental Panel of Climate Change. Cambridge University Press, Cambridge, pp 659-708

Arkell BP, Darch GJC (2006) Impact of climate change on London's transport network. Proc Inst Civil Eng: Munic Eng 159:231-237. doi:10.1680/muen.2006.159.4.231

Armington PS (1969) A theory of demand for products distinguished by place of production. Staff Pap - Int Monet Fund 16:159. doi: $10.2307 / 3866403$

Bachner G, Bednar-Friedl B, Nabernegg S, Steininger KW (2015) Economic evaluation framework and macroeconomic modelling. In: Steininger KW, König M, Bednar-Friedl B, Kranzl L, Loibl W, Prettenthaler F (eds) Economic evaluation of climate change impacts: development of a cross-sectoral framework and results for Austria. Springer, Berlin, pp 101-120

Bednar-Friedl B, Wolkinger B, König M, Bachner G, Formayer H, Offenthaler I, Leitner M (2015) Transport. In: Steininger KW, König M, Bednar-Friedl B, Kranzl L, Loibl W, Prettenthaler F (eds) Economic evaluation of climate change impacts: development of a cross-sectoral framework and results for Austria. Springer, Berlin, pp 279-300

Berrittella M, Bigano A, Roson R, Tol RSJ (2006) A general equilibrium analysis of climate change impacts on tourism. Tour Manag 27:913-924. doi:10.1016/j.tourman.2005.05.002

Beuthe M, Jourquin B, Urbain N, Lingemann I, Ubbels B (2014) Climate change impacts on transport on the Rhine and Danube: a multimodal approach. Transp Res D Transp Environ 27:6-11. doi:10.1016/j.trd.2013.11.002

Bigano A, Bosello F, Roson R, Tol RSJ (2008) Economy-wide impacts of climate change: a joint analysis for sea level rise and tourism. Mitig Adapt Strat Glob Change 13:765-791. doi:10. 1007/s11027-007-9139-9

Bosello F, Nicholls RJ, Richards J, Roson R, Tol RSJ (2012) Economic impacts of climate change in Europe: sea-level rise. Clim Change 112:63-81. doi:10.1007/s10584-011-0340-1

Chinowsky P, Arndt C (2012) Climate change and roads: a dynamic stressor-response model. Rev Dev Econ 16:448-462. doi:10. 1111/j.1467-9361.2012.00673.x

Chinowsky PS, Strzepek K, Larsen P, Opdahl A (2010) Adaptive climate response cost models for infrastructure. J Infrastruct Syst 16:173-180. doi:10.1061/(ASCE)IS.1943-555X.0000021

Ciscar JC, Iglesias A, Feyen L, Szabó L, Van Regemorter D, Amelung B, Nicholls R, Watkiss P, Christensen OB, Dankers R, Garrote L, Goodess CM, Hunt A, Moreno A, Richards J, Soria A (2011) Physical and economic consequences of climate change in Europe. Proc Natl Acad Sci USA 108:2678-2683. doi:10. 1073/pnas. 1011612108

Ciscar JC, Feyen L, Soria A, Lavalle C, Raes F, Perry M, Nemry F, Demirel H, Rozsai M, Dosio A, Donatelli M, Srivastava A, Fumagalli D, Niemeyer S, Shrestha S, Ciaian P, Himics M, Van Doorslaer B, Barrios S, Ibanez N, Forzieri G, Rojas R, Bianchi A, Dowling P, Camia A, Liberta G, San-Miguel-Ayanz J, de Rigo D, Caudullo G, Barredo J, Paci D, Pycroft J, Saveyn B, Van Regemorter D, Revesz T, Vandyck T, Vrontisi Z, Baranzelli C, Vandecasteele I, Batista e Silva F, Ibarreta D (2014) Climate Impacts in Europe. Results from the JRC PESETA II Project. ftp.jrc.es/EURdoc/JRC87011.pdf. Accessed 07 May 2014

Darwin RF, Tol RSJ (2001) Estimates of the Economic Effects of Sea Level Rise. Environ Resource Econ 19:113-129. doi:10.1023/A: 1011136417375

de Bruin KC, Dellink RB, Tol RSJ (2009a) AD-DICE: an implementation of adaptation in the DICE model. Clim Change 95:63-81. doi:10.1007/s10584-008-9535-5

de Bruin K, Dellink R, Agrawala S (2009b) Economic aspects of adaptation to climate change (OECD Environment Working Papers No. 6). doi: $10.1787 / 225282538105$

Deke O, Hooss KG, Kasten C, Klepper G, Springer K (2001). Economic impact of climate change: simulations with a regionalized climate-economy model, Kiel Working Paper No. 1065. Kiel Institute of World Economics, Kiel. http://mercury.ethz.ch/ serviceengine/Files/ISN/124059/ipublicationdocument_singledo cument/0b9b28a4-e751-4488-add4-62ffde7dd75e/en/kap1065. pdf. Accessed 14 May 2014

Doll C and Sieber N (2010) Vulnerability assessment for road transport. contribution to deliverable 2: transport sector vulnerabilities within the research project. http://www.weather-project. eu/weather/downloads/Deliverables/WEATHER_D2_Appen dix-B_Annexes-by-Mode_20110610.pdf. Accessed 14 Mar 2014

Dulac J (2013) Global land transport infrastructure requirementsestimating road and railway infrastructure capacity and costs to 2050. OECD/IEA, Paris. https://www.iea.org/publications/free publications/publication/TransportInfrastructureInsights_ FINAL_WEB.pdf. Accessed 23 Nov 2013 
European Union (2012) EU transport in figures. Statistical pocketbook 2012. Publications Office of the European Union, Luxembourg. http://ec.europa.eu/transport/sites/transport/files/factsfundings/statistics/doc/2012/pocketbook2012.pdf. Accessed 23 May 2013

EUROSTAT (2014) Structural business statistics. Annual detailed enterprise statistics for services (NACE Rev. $2 \mathrm{H}-\mathrm{N}$ and S95) (sbs_na_1a_se_r2)

Frei C, Schöll R, Fukutome S, Schmidli J, Vidale PL (2006) Future change of precipitation extremes in Europe: intercomparison of scenarios from regional climate models. J Geophys Res. doi:10. 1029/2005JD005965

Gobiet A, Kotlarski S, Beniston M, Heinrich G, Rajczak J, Stoffel M (2014) 21st century climate change in the European Alps-a review. Sci Total Environ 493(1138):1151. doi:10.1016/j.scito tenv.2013.07.050

Hallegatte S, Hourcade JC, Dumas P (2007) Why economic dynamics matter in assessing climate change damages: illustration on extreme events. Ecol Econ 62:330-340. doi:10.1016/j.ecolecon. 2006.06.006

Halsnæs K, Kühl J, Olesen J (2007) Turning climate change information into economic and health impacts. Clim Change 81:145-162. doi:10.1007/s10584-006-9221-4

Hawkes P, Pauli G, Moser H, Arntsen Ø, Gaufres P, Mai S, White K (2010) Impacts of climate change on waterborne transport. Proc Inst Eng Civ Eng 163:55-63. doi:10.1680/cien.2010.163.5.55

Hofstätter M, Mattula C (2010) PRISK-CHANGE Veränderung des Risikos extremer Niederschlagsereignisse als Folge des Klimawandels. Abschlussbericht der Fachabteilung Klimavariabilität/Modellierung in der Abteilung Klimaforschung. ZAMG, Vienna. http://www.zamg.ac.at/docs/forschung/klimato logie/endbericht_priskchange.pdf. Accessed 02 April 2014

Hope $\mathrm{CW}$ (2006) The marginal impacts of $\mathrm{CO}_{2}, \mathrm{CH}_{4}$ and $\mathrm{SF}_{6}$ emissions. Clim Policy 6:537-544

Hunt A, Watkiss P (2011) Climate change impacts and adaptation in cities: a review of the literature. Clim Change 104:13-49. doi:10. 1007/s10584-010-9975-6

Jongman B, Hochrainer-Stigler S, Feyen L, Aerts JCJH, Mechler R, Botzen WJW, Bouwer LM, Pflug G, Rojas R, Ward PJ (2014) Increasing stress on disaster-risk finance due to large floods. Nat Clim Change 4:264-268. doi:10.1038/nclimate2124

Kirshen P, Ruth M, Anderson W (2006) Climate's long-term impacts on urban infrastructures and services: The case of Metro Boston. In: Ruth M, Donaghy K, Kirshen P (eds) Regional climate change and variability: impacts and responses. Edward Elgar, Cheltenham, pp 190-252

Kirshen P, Knee K, Ruth M (2008) Climate change and coastal flooding in Metro Boston: impacts and adaptation strategies. Clim Change 90:453-473. doi:10.1007/s10584-008-9398-9

Koetse MJ, Rietveld P (2009) The impact of climate change and weather on transport: an overview of empirical findings. Transp Res D: Transp Environ 14:205221. doi:10.1016/j.trd.2008.12. 004

Kromp-Kolb H, Nakicenovic N, Steininger K, Gobiet A, Formayer H, Köppl A, Prettenthaler F, Stötter J, Schneider J (2014) Österreichischer Sachstandsbericht Klimawandel 2014 Austrian Panel on Climate Change (APCC)-Austrian Assessment Report 2014 (AAR14). Verlag der österreichischen Akademie der Wissenschaften, Vienna

Larsen PH, Goldsmith S, Smith O, Wilson ML, Strzepek K, Chinowsky P, Saylor B (2008) Estimating future costs for Alaska public infrastructure at risk from climate change. Glob Environ Change 18:442-457. doi:10.1016/j.gloenvcha.2008.03.005
LCCP (2005) Climate change and London's transport systems. Summary report. October 2005. London climate change partnership. Greater London Authority, London

Lofgren H, Harris RL, Robinson S (2002) A standard computable general equilibrium (CGE) model in GAMS. International Food Policy Research Institute, Washington, D.C. https://www.ifpri. org/cdmref/p15738coll2/id/74845/filename/74846.pdf. Accessed 12 Nov 2012

Nemry F, Demirel H (2012) Impacts of climate change on transport: a focus on road and rail transport infrastructures (No. Report EUR 25553 EN), JRC Scientific and Policy Reports. Joint Research Center, Luxembourg. ftp.jrc.es/EURdoc/JRC72217.pdf. Accessed 13 March 2014

Nordhaus WD (1992) An Optimal Transition Path for Controlling Greenhouse Gases. Science 258:1315-1319

ÖBB (2014) ÖBB Infrastruktur AG: Daten und Fakten. http://www. oebb.at/infrastruktur/de/2_0_Das_Unternehmen/Daten_und_Fak ten/index.jsp Accessed 16 Oct 2014

OCA (2005) Climate change will impact the Seattle department of transportation. Office of City Auditor. http://www.seattle.gov/ light/News/Issues/Green/Climate_Change_Presentation_10_31_ 05.pdf. Accessed 02 Nov 2015

OECD (2015) The economic consequences of climate change. OECD, Paris

Paltsev S (2004) Moving from Static to Dynamic General Equilibrium Economic Models (Notes for a beginner in MPSGE). Joint Program on the Science and Policy of Global Change Massachusetts Institute of Technology, Cambridge, Massachusetts. http://web.mit.edu/paltsev/www/docs/move04.pdf. Accessed 24 Feb 2012

Pindyck RS (2013) Climate change policy: what do the models tell us? J Econ Lit 51:860-872. doi:10.1257/jel.51.3.860

Regmi MB, Hanaoka S (2011) A survey on impacts of climate change on road transport infrastructure and adaptation strategies in Asia. Environ Econ Policy Stud 13:21-41. doi:10.1007/s10018-0100002-y

Rutherford TF (1995) Extension of GAMS for complementarity problems arising in applied economic analysis. J Econ Dyn Control 19:1299-1324. doi:10.1016/0165-1889(94)00831-2

Schweighofer J (2014) The impact of extreme weather and climate change on inland waterway transport. Nat Hazards 72:23-40. doi:10.1007/s11069-012-0541-6

Shoven JB, Whalley J (1992) Applying general equilibrium. Cambridge University Press, Cambridge

Sims R, Schaeffer R, Creutzig F, Cruz-Núñez X, D’Agosto M, Dimitriu D, Figueroa Meza MJ, Fulton L, Kobayashi S, Lah O, McKinnon A, Newman P, Ouyang M, Schauer JJ, Sperling D, Tiwari G (2014) Transport. In Edenhofer O, Pichs-Madruga R, Sokona Y, Farahani E, Kadner S, Seyboth K, Adler A, Baum I, Brunner S, Eickemeier P, Kriemann B, Savolainen J, Schlömer S, von Stechow C, Zwickel T, Minx JC (eds) Climate change 2014: mitigation of climate change. Contribution of Working Group III to the Fifth Assessment Report of the Intergovernmental Panel on Climate Change. Cambridge University Press, Cambridge

Steininger KW, König M, Bednar-Friedl B, Kranzl L, Loibl W, Prettenthaler F (2015) Economic evaluation of climate change impacts. Development of a cross-sectoral framework and results for Austria. Springer, Berlin

Tol RSJ (1997) On the optimal control of carbon dioxide emissions: an application of FUND. Environ Model Assess 2:151-163

Watkiss P (2011) The ClimateCost Project. Final report. Volume 1: Europe. Stockholm Environmental Institute, Stockholm 